\title{
GST : A NEW ERA OF INDIRECT TAXES
}

\section{Dr. Prafull C. Thakkar}

\begin{abstract}
There are distinguishing indirect taxes functional on services and goods by the Government of India and state government of India. Goods \& Services Tax is planned to incorporate all these taxes into one tax with consistent ITC and charged on both goods and services. Accordingly excise duty, special additional duty, service tax, VAT to give some examples will get cancelled and will be included into GST. For this, Goods \& Services Tax will have 3 sections - CGST (Central Goods \& Services Tax), SGST (State Goods \& Services Tax), and IGST (Integrated Goods and Services Tax). The focal duties like extract obligation will be subsumed into CGST and state charges like VAT into SGST. Financial service industry, specifically financial institutions like Banks and NBFCs are the backbone of any economy. They are the drivers of the economy and contribute roughly $6 \%$ of the roundabout charges. Accordingly they are a huge player and an unfavourable effect on the segment impacts the economy. Further, Banks presently work just in the service area and are secured by Service Tax @ 12.36\% right now. Going ahead with GST (Goods \& Services Tax), they should pay approx. 27\% GST. This paper examined information gathered from inquires about articles and data for worldwide practices for comparative issues and information gathered through meeting and poll from individuals in the field. In view of this investigation, the paper goes ahead to propose changes or necessities that GST should address from a financial service industry perspective.
\end{abstract}

Keywords: GST, IGST, CGST, Service Tax, VAT. 


\section{INTRODUCTION}

Taxation is a fiscal tool in the hands of the Government to raise revenue for the country and indirect taxes like excise duty, customs duty, value added tax, service tax, proposed goods and service tax, etc. are some of the taxes which contribute majorly to raise this revenue.

The proposed move to GST by the Indian Government which would combine most of these indirect taxes and be introduced as one common tax on both goods and services, is a step in this direction.

\section{BACKGROUND OF INDIRECT TAXES IN INDIA}

Broadly there are two types of taxes - 'Direct taxes and indirect taxes'. Direct taxes are called as such because they are a tax on income earned by an individual/entity and are directly paid by the individual/entity earning the income to the government. Thus the entity or individual earning income pays tax on its taxable income determined as per the provisions of law to the Government. The slab rates of the income tax are progressive i.e. they increase with the increase in income. Hence direct taxes are considered as progressive since they rise with a rise in income and are directly proportional to the income.

However, in the case of indirect taxes, these are imbedded in the costs of goods and services (like excise, customs duty, service tax etc.) and are collected by the seller/provider of such goods/services from the final consumer of the goods/services and paid to the government. Thus though the tax is borne by the consumer, it is paid to the government by the seller of goods or provider of services. Hence the tax is an indirect tax borne by one and paid by another.

Further these taxes being included in the cost of the product, are paid by all irrespective of the income level. Hence indirect taxes are considered as regressive in nature.

Excise duty, customs duty, Central Sales Tax, Value Added Tax, Luxury Tax, Entertainment tax, Service Tax etc. are the various types of indirect taxes.

Historically in India, indirect taxes were applicable only on goods and there were various indirect taxes operating in India. The main ones were Customs duty on 
imports, excise duty on manufacture and Sales Tax on sale of goods which later became Value Added Tax or VAT. Thus goods which were tangible in nature were covered under the indirect tax net. Further, there was no concept of availability of input tax credit or ITC set off against the output tax liability other than under excise i.e. in the form of Cenvat credit on manufacture of goods. Thus the cost of goods sold was higher due to tax being charged on tax.

Further for interstate movement of goods, Central Sales Tax or CST is charged. CST is payable to the state where the transaction originates. It is paid by the buyer of the goods in the destination state. This is contrary to the model of IGST proposed in the coming GST where the IGST is payable to the destination state and not the origination state.

\section{GOODS AND SERVICES TAX (GST)}

Goods and Services Tax (GST) is an indirect tax which was introduced in India on 1 July 2017 and was applicable throughout India which replaced multiple cascading taxes levied by the central and state governments. It was introduced as The Constitution (One Hundred and First Amendment) Act 2017, following the passage of Constitution 122nd Amendment Bill. The GST is governed by a GST Council and its Chairman is the Finance Minister of India. Under GST, goods and services are taxed at the following rates, $0 \%, 5 \%, 12 \%, 18 \%$ and $28 \%$. There is a special rate of $0.25 \%$ on rough precious and semi-precious stones and $3 \%$ on gold. In addition a cess of $15 \%$ or other rates on top of $28 \%$ GST applies on few items like aerated drinks, luxury cars and tobacco products. GST was initially proposed to replace a slew of indirect taxes with a unified tax and was therefore set to dramatically reshape the country's 2 trillion dollar economy. The rate of GST in India is between double to four times that levied in other countries like Singapore

\section{OBJECTIVES OF THE STUDY}

- To comprehend the existing Indian economy and the economic policies specifically in relation to financial services supply provisions

- To study the options existing to tax financial services supply under GST and impact thereof 
- To study the assesses / tax professionals viewpoint on the proposed provisions under GST in relation to compliances for financial services

\section{LITERATURE REVIEW}

Aamir, (2011) The authors in this paper have studied the composition of direct and indirect taxes in the total revenue generation for the Government in India and Pakistan over a period of time, for period 1999-00 to 2008-09. The reason is that indirect taxes increase the inequality between the rich and poor i.e. it is regressive in nature whereas direct taxes are more progressive. Direct tax or income tax is generally a tax on the income earned. Hence more the income earned higher is the tax paid. Thus direct taxes are considered as progressive in nature.

However, irrespective of the income levels, indirect taxes which are taxes imbedded in the costs of goods and/or services consumed are paid by every person/entity rich or poor at the time of consumption. Thus the tax is considered regressive. Hence a country does better to rely on direct taxes for its revenue generation so that the progress is better.

The authors have concluded that India relies on direct taxes and Pakistan on indirect taxes for its revenue generation. The impact of this could be that in Pakistan the inequality between rich and poor will go on increasing and the labour class will suffer.

Ahmad, (2010) the author in this paper has discussed the efforts of Pakistan Government to implement General Sales Tax in Pakistan. The author has discussed the existing indirect tax system in Pakistan, the history of the tax system in Pakistan, the reforms recommended by the National Taxation Reforms Commission and then highlighted the issues and benefits in the proposed reforms.

Benedict, (2011) The author studies the law provisions dealing with financial services under the Australian GST law with the intention to verify whether the provisions have been construed correctly in light of the original purpose of the legislation and how the concerns identified may be rectified. 
Bhat, (2014) the author in the paper has discussed e governance of the VAT system in India with specific reference to Goa and Kerala. India had the system of sales tax which was quite complicated up to almost 2005.In 2005, lot of states adopted the Value Added Tax instead of sales tax, Goa and Kerala being two of them. The main advantage of VAT was the availability of ITC on goods purchased.

Bikas, (2013) the authors have studied the VAT rate and the EU economy and also the link between the VAT and macroeconomic indicators and their influence on the VAT rate. The authors have tried to identify the factors impacting the VAT collections in the EU countries.

Ciobanasu (2012) the authors trace the correlation between the types of taxes and their role in the budgeted revenues and the fiscal development of Romania. Indirect tax by its very nature is easier to govern, is neutral to status of tax payer, and increases revenue but leads to inflation. On the other hand direct taxes depend on the tax payer and are difficult to govern. Further, indirect tax helps the government to an extent to direct consumption of the public. The authors conclude that both the taxes are important for overall growth of the economy.

Collins, (2014) The author in this paper has studied and evaluated the contributions by households to the direct and indirect tax collections in Ireland. Further these contributions and the impact thereon are studied in the light of the recent reforms in indirect tax undertaken in Ireland.

Deloitte, (2014) in this paper Deloitte provides a summary of the changes proposed in the Place of Supply Rules for e services, telecommunication services and broadcasting services from 1 January 2015 in the European Union. This paper is highly relevant from an Indian GST and financial services perspective, since India has a dual government and financial services are also intangible like e services. In brief the new rules propose that the e services provided to private customers and non-registered customers i.e. B2C supplies will be taxable in state where customer is located. This is contrary to the existing rules in the EU, where such supplies are taxable where the supplier is located.

Emmanuel, (2013) the author has examined the link between VAT, the increase in VAT rates and the economic growth and tax revenue in Nigeria. For this study the author has set out 2 Null hypothesis which are post the research accepted. The author 
concludes that given the strong relation between the above, the Government and authorities should actively educate the public on the benefits of VAT so that they accept changes in VAT rates more easily.

Fathi, (2012) the authors have explored the connection between the rate of VAT and the evasion of VAT by the public using varied experimental methods. They conclude that there is no connection between the two because in many countries where the VAT rate is high the compliance is also high and where it is low the evasion is high.

Feria, (2009) the authors in this paper study the taxation under indirect taxes specifically of financial services in Australia and the EU and whether the Australian system of taxation is better. Further in case the Australian system is better whether there are any points which can be implemented in the EU.

Gelardi (2013) the author in the paper has studied the expected impact on consumers of the proposed National Consumption Tax to be introduced in USA since it would mean additional costs to the consumers. This proposed tax would be federal and in addition to the existing state sales tax in the various states of the US.

Genpact, (2011) In this paper, Genpact has in brief stated how the outcome of the study conducted by them for a manufacturing client to whom European VAT was applicable, saved money due to certain process changes in handling VAT related compliances by the client.

Halakhandi, (2007) GST was supposed to be introduced in India way back in 2010.It has been getting postponed due to various reasons major one being getting to a consensus between the various states and the centre for compensation. The author in the paper has discussed the existing laws in India for indirect taxes, the VAT laws in various states with their advantages and disadvantages, the impact of the proposed GST, the compliances under the proposed GST etc. The author has also used various numerical examples to demonstrate how GST is cost effective.

Herekar, (2012) The Ministry of Finance had set up the Task Force with Mr. V. Kelkar as the chairman of the Task Force. The main task of the Task Force was to evaluate the impact of the proposed GST on the Indian economy. The author in the paper has studied the different parts of GST and their impact on the common man, the business and the economy. The author has concluded based on secondary data that if 
GST is introduced in India, it would have a positive impact on the overall economy. The author has specifically discussed the types of GST i.e. CGST , SGST and IGST, the exemptions under GST, the treatment of imports and exports under GST, the adjustments of ITC etc.

Jan, (2011) The author has explored in the paper how to 'manage' indirect taxes like VAT, Sales Tax, Use or Consumption Tax etc. effectively. For this the author has studied practices followed by various multinationals and concluded for effective management it is necessary to have proper processes, advanced software and external checks by auditors. The author states that for good management it is necessary to have automated processes right from tax collection, reporting to tax payment. Further there should be central responsibility for tax reporting and as far as possible the processes should be standard.

Kabera, (2009) the author in this paper has studied the various measures available and used under the Rwanda Tax Law to control offences under Tax laws.The author has studied the strong and weak points of such measures and tried to identify steps to improve on the same so that tax offences are better controlled.

Mawuli, (2014) the author has evaluated the existing GST framework in Papua New Guinea -PNG and suggested measures to improve on the negative impact of the same. The paper examines the reasons for adopting GST in PNG, its impact on the PNG economy and the reforms or changes to be carried out in the GST law for betterment.

Parkhi, (2010) The author in the paper has discussed the concept of GST to be introduced in India, the background to GST and the method of collecting the proposed GST especially in light of the federal nature of administration in India. The author has discussed the various indirect taxes like VAT, excise etc. currently operating in India. Roychowdhury, (2011) The author in his paper has explored the existing indirect tax of VAT and then gone on to explore the law surrounding the proposed GST to be introduced in India along with the benefits thereof and the issues in implementing the same. The author has discussed how GST is supposed to encompass both goods and services. Further the author has discussed how in India it has been proposed to introduce SGST and CGST. 
Zhou, (2013) the authors in this paper analyse the Malaysia GST. The authors have first in short summarized the existing issues in the Malaysian economy with comparisons to the proposed GST. The paper also studies the impact of the GST on the price levels, growth of the economy, the revenue generation etc. The paper states that GST would generally bring down the prices and increase the GDP - this is as expected in Indian context also.

\section{DATA ANALYSIS}

1. Table of number of members in tax team

\begin{tabular}{|l|c|}
\hline VARIABLE & $\begin{array}{c}\text { NO OF } \\
\text { RESPONDENTS }\end{array}$ \\
\hline $0-5$ & 11 \\
\hline $6-10$ & 7 \\
\hline More than 10 & 22 \\
\hline TOTAL & 40 \\
\hline
\end{tabular}

Inference - This indicates the importance of tax in a financial institution /industry. It shows that the industry considers it necessary to have at least 10 members in the tax team to deal with the day to day complexities.

The same thing can be seen directly from the bar chart above. Majority respondents have answered that they have more than 10 members in the tax team.

2. Table of whether separate indirect IDT

\begin{tabular}{|l|c|}
\hline VARIABLE & $\begin{array}{c}\text { NO OF } \\
\text { RESPONDENTS }\end{array}$ \\
\hline Yes & 29 \\
\hline No & 7 \\
\hline $\begin{array}{l}\text { Not } \\
\text { Applicable }\end{array}$ & 4 \\
\hline TOTAL & 40 \\
\hline
\end{tabular}

As can be seen from the above table and pie chart, $72 \%$ majority of the respondents have a separate indirect or IDT team. 
Towards Excellence: An Indexed, Refereed \& Peer Reviewed Journal of Higher Education / Dr. Prafull Thakkar / Page 199-211

Inference - This indicates that industry perceives indirect taxes and GST crucial to the future of tax functioning.

3. Table of number of indirect tax - IDT members in tax team

\begin{tabular}{|l|c|}
\hline VARIABLE & $\begin{array}{c}\text { NO OF } \\
\text { RESPONDENTS }\end{array}$ \\
\hline $0-5$ & 14 \\
\hline More than 5 & 21 \\
\hline Not applicable & 5 \\
\hline TOTAL & 40 \\
\hline
\end{tabular}

As can be seen 21 out of 40 respondents have answered that they have 5members in their tax team. Thus more than half of respondents range.

4. Table of percentage of IDT paid to total tax paid

\begin{tabular}{|l|c|}
\hline VARIABLE & NO OF RESPONDENTS \\
\hline $0-10 \%$ & 12 \\
\hline $11-25 \%$ & 24 \\
\hline $26-50 \%$ & 3 \\
\hline More than $50 \%$ & 1 \\
\hline TOTAL & 40 \\
\hline
\end{tabular}

As can be seen above, the indirect taxes are in the range of $11-25 \%$ for more than half i.e. $60 \%$ of the respondents. Around hone third - 30\% are paying IDT which is in the range of $0-10 \%$ of their total tax outflow. Very few respondents - only $3 \%$ pay indirect taxes of more than $50 \%$ of their total taxes and $7 \%$ pay between 26$50 \%$.These figures are in relation to financial year 2011-12.Thus most respondents pay indirect taxes in the range of $11-25 \%$ of their total tax outflow

5. Table of percentage of IDT paid to total tax paid

\begin{tabular}{|l|c|}
\hline VARIABLE & $\begin{array}{c}\text { NO OF } \\
\text { RESPONDENTS }\end{array}$ \\
\hline $0-10 \%$ & 12 \\
\hline $11-25 \%$ & 23 \\
\hline $26-50 \%$ & 4 \\
\hline More than $50 \%$ & 1 \\
\hline
\end{tabular}


\begin{tabular}{|l|l|} 
TOTAL & 40 \\
\hline
\end{tabular}

As can be seen above, the indirect taxes are in the range of $11-25 \%$ for more than half i.e. $57 \%$ of the respondents. Around hone third $-30 \%$ are paying IDT which is in the range of $0-10 \%$ of their total tax outflow. Few Respondents - only 3\% pay indirect taxes of more than $50 \%$ of their total taxes and $10 \%$ pay $26-50 \%$ of the total taxes. Thus most respondents pay indirect taxes in the range of $11-25 \%$ of their total tax outflow

\section{CONCLUSION}

It can be presumed that Service tax integral and separate part of tax, needing dedicated resources, mainly due to oncoming GST, Indirect taxes form a huge proportion of total taxes paid and hence GST bound to have a huge impact. Respondents are Satisfied with current provisions with no change required in GST. IGST being the preferred option to be presented with complete lucidity. Consistence and related provisions should be explicit and clear without any issues due to multistate compliances

\section{SUGGESTIONS}

- Better awareness and education to public with enough time to interpret and adapt to the new law

- All state level taxes need to be included in SGST - States should not be allowed to push for and keep parallel taxes

- Similarly the Centre needs to include all its taxes (other than import duties like customs) in CGST

- The rate of GST needs to be very reasonable - maximum 20\%.Further there should not be multiple rates (necessities may be having lower rates) and the rates have to be common across India

- Unified common procedures should be followed. The base for exemptions, threshold limits, abatements should be same for both centre and all states to avoid interpretation issues and litigation. Else India will face problems like the EU 
- There should be audits every year like under direct taxes rather than for a block period of 5 years. 5 years is too much of data to be collated, reconciled etc. Under GST it would become even more cumbersome

- Date of payment of GST should be 10th of the following month. Given the complexities in the laws, difficulties in collating data for so many states, 6th of the following month might be difficult to achieve

- Revision of return time limits should be increased

- The basic threshold exemption limit should be higher to keep small traders out of the GST compliances

- The provisions of law in relation to basic concepts, meaning of services, goods, their taxability, place of supply etc. should be clear and unambiguous and should be part of the law or rules (not part of education guide which does not have the authority of law)

- There should be very few exemptions on the output side and exclusions on the input side to avoid break in the credit chain and achieve the objective of reducing the effect of tax on tax.

- Double taxation of income like interchange, correspondent bank charges should be addressed

\section{BIBLIOGRAPHY}

- $\quad$ Aamir M., Qayyum A., Nasir A., Hussain S., Khan K. and Butt S., 2011, Determinants of Tax Revenue: A Comparative Study of Direct taxes and Indirect taxes of Pakistan and India, International Journal of Business and Social Science, Vol. 2, Issue 19, Pg. 173-178

- $\quad$ Ahmad E., 2010, Why is it so Difficult to Implement a GST in Pakistan?, The Lahore Journal of Economics, Vol. 15, Pg. 139-169

- $\quad$ Benedict K., 2011, The Australian GST regime and financial services: How did we get here and where are we going?, E Journal of Tax Research, Vol. 9, (Issue 2), Pg. 174-193

- $\quad$ Bhat S., 2014, E-Governance of Value Added Tax System: Comparative study with reference to Goa and Kerala, Global Research Analysis, Vol.3, Issue3, Pg. 3-4 
Towards Excellence: An Indexed, Refereed \& Peer Reviewed Journal of Higher Education / Dr. Prafull Thakkar / Page 199-211

- $\quad$ Bikas E. and Andrukaite E., 2013, Factors affecting Value Added Tax revenue, European Scientific Journal, Vol. 1, Pg. 41-49

- $\quad$ Ciobanasu M. and Postole M., 2012, Contribution of Taxes to the making up of Budget Revenues in the Economic Growth, Journal of Knowledge Management, Economics and Information Technology, Vol. 2, (Issue 6), Pg. $1-12$

- $\quad$ Collins M., 2014, Total Direct and Indirect Tax contributions of Households in Ireland: Estimates and Policy Simulations, Nevin Eco. Research Institute WP Series, Vol 18, Pg. 1-41

- Deloitte, 2014, EU: 2015 Place of Supply changes: Changes to the VAT place of Supply for e-services, Pg. 1-7

- $\quad$ Emmanuel U. 2013, The Effects of VAT on the Economic Growth of Nigeria, Journal of Economics and Sustainable Development, Vol. 4, (Issue 6), Pg. 190-201

- $\quad$ Fathi B. and Esmaeilian M., 2012, Evaluation of Value Added Tax and Tax Evasion, Current Research Journal of Economic Theory, Vol. 4, (Issue 1), Pg. $1-5$

- $\quad$ Feria R. and Walpole M., 2009, Options for Taxing Financial Supplies in Value Added Tax: EU VAT and Australian GST Models Compared, ICLQ, Cambridge Journals, Vol. 58, Pg. 897-932

- $\quad$ Gelardi M., 2013, VAT and Consumer Spending: A Graphical Descriptive Analysis, Asian Journal of Finance and Accounting, Vol. 5, Issue 1, Pg. 1-20

- $\quad$ Genpact, 2011, Improving Value Added Tax Processes Produces \$ .5MM P\&L Impact for a Global Manufacturer, Finance \& Accounting Case Study, Pg. $1-2$

- Halakhandi S., 2007, Goods and Service Tax - An introductory study, The Chartered Accountant, Pg. 1595-1601

- $\quad$ Herekar P.M., 2012, Evaluation of Impact of Goods and Service Tax, Indian Streams Research Journal, Vol. 2, (Issue 1), Pg. 1-4

- Jan W., 2011, Managing Value Added Tax (VAT) in a Global Environment, Aberdeen Group Journal, Pg. 1-23 
Towards Excellence: An Indexed, Refereed \& Peer Reviewed Journal of Higher Education / Dr. Prafull Thakkar / Page 199-211

- $\quad$ KaberaC., 2009, A Critical Analysis of Effectiveness of Tax Offences Control Mechanisms under Rwandan Law, Research Paper - Kigali Independent University, Pg. 1-59

- $\quad$ Mawuli A., 2014, Goods and Service Tax: An Appraisal, Discussion Paper, PNG Taxation Research and Review Symposium, National Research Institute, Pg. 1-14

- $\quad$ Parkhi S., 2010, Goods and Service Tax: The changing face of the Economy, Pg. 1-15

- $\quad$ Roychowdhury, 2011, VAT and GST in India - A Note, Economic WP Series, Centre for Training and Research in Public Finance and Policy, Vol. 6, Pg. 114

- Zhou L., Tam J and Heng-Contaxis J., 2013, The Introduction of Goods and Services Tax in Malaysia, Centre for Public Policy Studies, Pg. 1-29

\author{
Dr. Prafull C. Thakkar \\ Assistant Professor \\ C.S.Samariya Commerce College, \\ Maninagar Ahmedabad \\ Email Id: thakkar.prafull@yahoo.com \\ Mob.Number:9099088801
}

